\title{
Playing SAFMEDS and Its Influence on the Vocabulary Learning of Hotel Department Students
}

\author{
Hardianti \\ hardi_anti11@yahoo.co.id \\ Universitas Muhammadiyah Luwuk Banggai, Indonesia \\ Haryanto Atmowardoyo \\ haryanto@unm.ac.id \\ Universitas Neheri Makassar, Indonesia \\ Kisman Salija \\ kismansalija@unm.ac.id \\ Universitas Negeri Makassar, Indonesia
}

ABSTRACT

\begin{abstract}
Playing Say All Fast Minute Every Day Shuffled (SAFMEDS), a set of cards containing details in both sides of the cards, has successfully helped many training of fluency and vocabulary development abroad (Quigley (2004); Kubina, Yurich, Durica, \& Healy (2015); Beverly, Huge, \& Hastings (2016)). However, none of them conducted their researches in the context of vocative education, and focused on English as a Foreign Language (EFL) or English for Specific Purposes (ESP). Thus, by intentionally opening the chance of adapting and transforming SAFMEDS to be applied in vocational high school classroom, the researcher conducted this study to find out whether or not there was any significant difference between the use of SAFMEDS and wordlist in vocabulary learning of two hotel department classrooms, and what are the aspects of vocabulary that might be highly influenced by SAFMEDS itself. This study was conducted purposively in the second grade of hotel department of SMK Negeri 3 Luwuk in the first term of 2017/2018 academic year. An English vocabulary test was administered to collect quantitative data by focusing on playing SAFMEDS containing hotel department terminologies as the core material. Through quasi-experimental research design, the analysis of quantitative data showed that there was a significant difference between the mean score of the students who were learning vocabulary by using SAFMEDS and the mean score of the students who were learning vocabulary by using wordlist. As for the second research question, the researcher found that the aspect of vocabulary which was dominantly affected by the use of SAFMEDS was the aspect of vocabulary in term of form.
\end{abstract}

Keywords: SAFMEDS, vocabulary learning

\section{INTRODUCTION}

People often focus on grammar errors which lead them to a fear of being wrong in learning a new language. It means they do not adequately understand that their anxiety only traps them into longer ignorance. The most important that people should note is that language is none other than the collection of words. Those words, in any language they are learning, should be understood as their assets to go 
further with the new language. That is because, actually, the difference between people, as the language learners and native speakers of the target language was their lexical competence (Laufer, 1998). Someone with adequate words collection will be able to create more meaningful sentences rather than someone who just knows a small number of words. Folse in Pekka (2013) noted that improving vocabulary has a direct and positive impact to build up someone's capacity in language proficiency as a whole.

The most common way to learn vocabulary is learning by using dictionaries. Astika (2016) assumes that the learners' awareness of the role of vocabulary will be reflected when they consult dictionaries for difficult vocabulary items. However, such a way of learning can be time-consuming (Mehring, 2005). Mehring (2005) suggests that rather developing lessons which allow learners to encounter new words multiple times, it is better to develop word lists from the context of the lesson can reduce the workload, enabling the student to encounter the word multiple times through reading, listening, and speaking.

Say All Fast Minute Every Day Shuffled (SAFMEDS) is one of the tools which is often used in Precision Teaching methodologies. The abbreviation refers to say the contents of all cards aloud within a brief time period every day after shuffling the cards (Quigley, 2014). It is very helpful for students to become fluent in definitions and basic concepts, and therefore ideally suited to practicing vocabulary of two languages ((Beverly, Hughes, \& Hastings, 2016). In this case, students are trained to develop their vocabulary by practicing some packages of SAFMEDS.

Based on the background, the purposes of this study are to find out:

1. Whether or not there is any significant difference between the average score of the students who are treated by using SAFMEDS and the average score of the students who are treated by using wordlist in their vocabulary learning.

2. The aspects of vocabulary which are dominantly affected by the use of SAFMEDS.

\section{LITERATURE REVIEW}

Some previous studies have been reviewed. The first and second studies are related to SAFMEDS (Meindl, Ivy, Milller, Williamson, \& Neef (2013); Kubina Jr.,Yurich, Durica, \& Healy, 2015). The two previous studies are multi work projects since they were conducted by more than one researcher for each. This current research was still dealing with SAFMEDS, but under the responsibility of a single researcher. Besides, there is also no research related to the implementation of SAFMEDS that have been specifically explored by the Indonesian researchers. Therefore, the researcher is interested to put the case into Indonesian context, especially in a non-mainstream school, which has low exposure of learning English. 
Other previous researchers also have done their studies related to the implementation of SAFMEDS. Besides Meindl et.al (2013), and Kubina Jr. et al (2015), Quigley (2014) and Beverly et al. (2016) also conducted SAFMEDS related researches. Whereas Quigley (2014 and Beverly et.al (2016) concerned with the fluency development of English speakers on other foreign languages, this current study took different target language. English was the target language that became the highlight of this study. The researcher also examined how well SAFMEDS influence three aspects of vocabulary namely form, meaning, and usage.

Related to the second variable and also as the dependent variable of this study, the researcher reviewed some research projects as well. It is important for anyone entering a profession to learn their profession's specialized language (Coxhead, Parkinson, \& Tu'amoheloa, 2017). This principle leads the third study which was conducted by Coxhead, et al. (2017). Their study revealed that knowledge of specialized language allows trades professionals to speak to other professionals and read technical material. Coxhead et al. (2017) are the same line with this current research in the case of its focus on profession's specialized language. Whereas they focused on automotive technology, this current research focus is on hotel accommodation world.

\section{METHOD}

This study used quantitative research with a quasi-experimental design. Thus, two groups namely experimental and control groups were involved. Besides, this study focused on implementing SAFMEDS cards in a non-mainstream school as an effort to enhance the result of vocabulary learning.

SAFMEDS is a set of cards containing details or information in one side of the cards and statement or words in another side of the cards. They were played and used as learning media in experimental class with two techniques: trial and real SAFMEDS cards. Trial means the students were only given ten cards to be played in twenty seconds while the real one means the students were given time to play a deck of cards consisting of forty cards within one minute (sixty seconds).

The population of this study was the grade XI students of SMK Negeri 3 Luwuk in academic year 2017/2018. The school is located in Jalan Raya Luwuk Nambo, in the district of Nambo, about 20 kilometers from Luwuk, the capital city of Banggai regency, Central Sulawesi. There are three skills departments in the grade XI of the school, namely Perhotelan (hotel management), Tata Busana (Fashion Design), and Jasa Boga (Food and Beverage Production). After verified the population, the researcher determined the sample of this research. Thus, this study purposively took class XI AKP A and class XI AKP B as the samples for their same department and level.XI AKP Awas the experimental class and the students of class XI AKP B was the control class. 
The main instrument of this study was an English vocabulary test. Paper-based form of English Vocabulary test was administered to students. The content of the test was mainly based on the hotel department. The test was given in pretest and posttest. There are 40 questions divided into three sections that must be answered by the students within 90 minutes.

There are several stages had been completed in order to collect the data of this study.The first was administering a pretest to know the prior knowledge of the students. After that, students in experimental class and control class had their different treatments. The experimental class was taught by using SAFMEDS while the control class was taught vocabulary by using a wordlist. The treatment lasted for four meetings for each class. The last stage was administering a posttest.

The procedure of data analysis also consisted of three stages, namely scoring the English vocabulary test, either as a pretest or a posttest of the students. Three sections of the test were analyzed separately before being calculated, in order to find the final obtained score of the students. Then, the scores are converted it in from 0 to 100 , to be classified whether they are poor, fair, good or very good; testing the hypothesis (by using t-test with $\alpha=0.05$ level of significance for independent sample), and taking the final conclusion in order to answer the research questions.

\section{FINDINGS AND DISCUSSIONS}

As one of the elements of language, vocabulary is essential for language learners to improve, no exception for English. This is because what makes the differences between language learners and native speakers are mainly in their lexical competence (Laufer, 1998). With adequate lexical competence, language learners may communicate effectively although they might not be like the real native speakers speaking style. Therefore, it is undeniable that acquiring more vocabulary is important. In addition, this study tried to find out in which vocabulary learning is influenced by the use of SAFMEDS.

\section{The Results of Pre-test and Post-test}

The first finding of this study was begun by the researcher's report after compared the mean score of the students in the experimental class and control class in pretest and posttest.

Figure 1: Mean Score and Standard Deviation (SD) of the Students of Experimental Class and Control Class in Pre Test and Post Test 


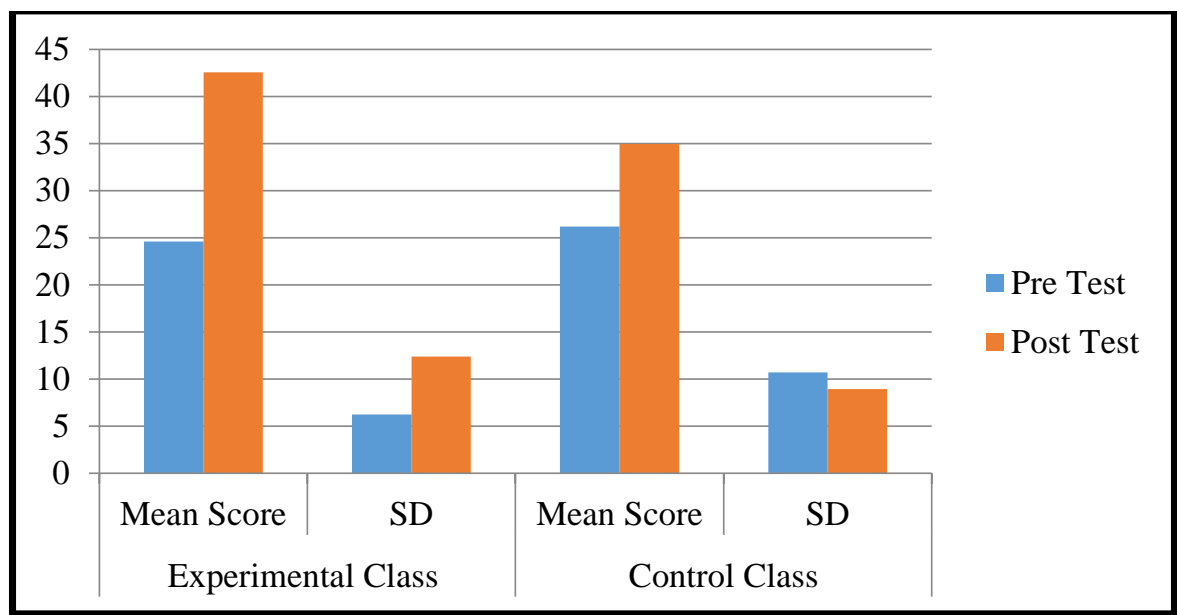

Figure 1 shows that the collection of English hotel department vocabulary of language learners, and in this case, students of the classes where the researcher took as research samples, was very bad. However, the researcher believes that this is not because they were never given such materials in the classroom. Based on the observation, the students had already had the collection of words regarding their special field but they were only given in separate subjects, not in English class. The materials of English lesson they usually had in the classroom were about the restricted grammatical materials, building up paragraphs, with the very less of hotel department integration. Therefore, the students simply thought that "I was learning English" not "I was learning how to be a good hotelier through English".

The result of the pretest then becomes the substantiation of the previous explanations. Although there were some of the students in control class got above very poor score, there were no students in the experimental class who got above that score level. This is suitable with the fact that said by the English teacher that the students of the two classes were simply had an average level of English but the students of AKP A (experimental class) were not as good as the students of AKP B (control class) in the case of their attitude and intention of learning. Returning back to her purpose of giving treatment for the class in which the students had lower achievement and condition, the researcher continued to take AKP A as the experimental class.

This condition was easy to control at the first time the researcher started the treatment in both the experimental class and the control class. All students were very enthusiastic about having the learning materials in the classrooms. However, it was not the same of what the researcher gave for students in experimental class and the students in the control class. 
The students in the experimental class had to play a deck of cards called SAFMEDS cards as the treatment after they were given materials under the topic of Front Office. The researcher explained the way to play SAFMEDS cards which were never played by any student before. After playing the cards, it was found that averagely only one card that can be solved by the students in 20 seconds time given in the first meeting but it had increased until the fourth meeting.

In contrast with the experimental class, the treatment in control class did not use SAFMEDS. However, the researcher still presented the same material or target words as experimental class. The theme of each meeting was also the same with that of the experimental class from the first until the fourth meeting. The themes were about Front Office, Room, Public Area, and Linen.

After having treated by the use of SAFMEDS cards, only one student in the experimental class got good score. In one hand, the eighteen students were still in the poor classification but their score had increased compared to the score in pretest. On the other hand, there was no one in control class got better than poor score. All students were mainly performed better compared to their pretest, but no one can be classified as fair, good, and very good.

\section{Testing Hypothesis}

From the post-test data, the researcher tested the hypothesis by using SPSS 21 . The level of significance is set at $\alpha=0.05$, df $=36$, and formula of the statistical hypothesis in this research was two-tailed. The result can be seen in the following table.

Table 2: T-Test and T-Table of the Students' Pre Test and Post Test

\begin{tabular}{cccc}
\hline df & Variable & T-Test Value & T-Table Value \\
\hline 36 & Pre Test & -0.558 & 2.028 \\
\hline 36 & Post Test & 2.172 & 2.028 \\
\hline
\end{tabular}

From table 2 , it can be seen that the t-test of students' pretest $(-0.558)$ was not higher than the t-table (2.028). In one word, the students of the experimental class got a lower result than the students in the control class. In another word, the students of experimental class did not perform better than the students in control class, and their vocabulary acquisition was still very low. Nevertheless, after they were given treatment, the t-test on posttest was higher (2.172) than the t-table (2.028). The analysis shows that the null hypothesis $\left(\mathrm{H}_{0}\right)$ was rejected and the 
alternative hypothesis $\left(\mathrm{H}_{1}\right)$ was accepted. It indicates that there was a significant difference between the mean score of the students who were treated by using SAFMEDS in their vocabulary learning and the mean score of the students who were treated by using wordlist in their vocabulary learning.

The decision of accepting the alternative hypothesis was also supported by the homogeneity of experimental class and control class. Based on Levene's Test for Equality of Variances (in SPSS) between the two classes in pretest, it was found that the two classes (XI AKP A and XI AKP B) were homogeny, proved by the result of significance $=0.021$ which was not higher than 0.05 . Therefore, it can be assumed that the difference of mean score of the two classes had something to do with the treatments that were also different, not because there was any internal difference inside the groups.

The fact that the students in experimental class can get higher score was also because they had practiced playing SAFMEDS cards regularly. However, despite of playing the cards regularly by taking minimum ten cards per meeting, the researcher had limited that each student should only practicing play one deck (ten cards) from one to three times in five meeting and practicing playing forty cards within one minute (60 seconds) in the last day of the treatment. In the same way, the practicing of playing ten cards from the four decks of cards confirmed to multiple exemplar training proposed by Meindl et al. (2013) and additional practice by Graff and Auman (2005). Then, in a different way, Beverly, Hughes, \& Hastings (2016) examined the use of SAFMEDS containing two different languages in two sides of the cards, played by a number of students in a mainstream school. Confirming to the result of the study conducted by Beverly, Hughes, \& Hastings (2016) which was difficult to see the correlation between the SAFMEDS cards practice frequency and the achievement of the students, this current research controlled the opportunity of exposure toward the cards. As a result, no matter the students had already accustomed to some important thing in SAFMEDS like how to hold the cards, manage the timer, decide partner, and fill in a playing recording sheet or not, had not been taken into account although the researcher believes that they also could be related.

\section{Aspect of Vocabulary}

Aspects of vocabulary are another thing the researcher examined in this research. It is about the percentage of the score of experimental class students related to aspects of vocabulary. The researcher had tried to find which one of the vocabulary aspects that had the highest improvement after the students in experimental class had played the SAFMEDS cards. The presentation of the result of this second question is presented in table 3 . 
ELT Worldwide Vol. 5 No. 2 (2018)

Hardiyanti, Atmowardoyo, Salija : Playing Safmeds and ...

Table 3: The Mean Score between Pretest and Posttest of Experimental Class in Three Aspects of Vocabulary

\begin{tabular}{cccc}
\hline \multirow{2}{*}{ Aspects of Vocabulary } & \multicolumn{2}{c}{ Mean Score } & Difference \\
& Pretest & Posttest & \\
\hline Form & 22.93 & 53.20 & 30.27 \\
Usage & 14.04 & 15.79 & 1.75 \\
Meaning & 36.84 & 58.68 & 21.84 \\
Mean Score of Overall Aspects & 24.60 & 42.56 & 17.96 \\
\hline
\end{tabular}

Table 3 shows the comparison between the mean score of students in Experimental Class before and after the treatment in three aspects of vocabulary. The aspect of vocabulary in term of form noted highest difference or improvement in 30.27 point before usage and meaning.

Table 4: The Mean Score between Pretest and Posttest of Control Class in Three Aspects of Vocabulary

\begin{tabular}{cccc}
\hline \multirow{2}{*}{ Aspects of Vocabulary } & \multicolumn{2}{c}{ Mean Score } & Difference \\
& Pretest & Posttest & \\
\hline Form & 19.17 & 42.67 & 8.03 \\
Usage & 14.91 & 8.77 & 0.47 \\
Meaning & 44.47 & 53.42 & 1.32 \\
Mean Score of Overall Aspects & 26.18 & 34.95 & 2.96 \\
\hline
\end{tabular}

Table 4 shows the comparison between the mean score of students in Control Class before and after the treatment in three aspects of vocabulary. Like the students in experimental class, the improvement score of the students in control class mostly in aspect vocabulary in term of form (8.03).

Table 5: The Mean Score of Pretest between Experimental Class and Control Class in Three Aspects of Vocabulary

\begin{tabular}{cccc}
\hline \multirow{2}{*}{ Aspects of Vocabulary } & \multicolumn{2}{c}{ Mean Score } & \multirow{2}{*}{ Difference } \\
& Experimental & Control & \\
\hline Form & Class & Class & 10.53 \\
Usage & 22.93 & 19.17 & 7.02 \\
Meaning & 14.04 & 14.91 & 5.26 \\
Mean Score of Overall Aspects & 36.84 & 44.47 & 8.01 \\
\hline
\end{tabular}


Table 5 shows the comparison between the mean score of pretest between experimental class and control class in three aspects of vocabulary. It can be noted that the mean score of experimental class in overall aspects was still lower than the mean score of control class. However, the 8.01 as difference score indicated that the two classes were homogeny, proved by the Levene's test of significance.

Table 6: The Mean Score of Posttest between Experimental Class and Control Class in Three Aspects of Vocabulary

\begin{tabular}{cccc}
\hline \multirow{2}{*}{ Aspects of Vocabulary } & \multicolumn{2}{c}{ Mean Score } & \\
& $\begin{array}{c}\text { Experimental } \\
\text { Class }\end{array}$ & $\begin{array}{c}\text { Control } \\
\text { Class }\end{array}$ & Difference \\
\hline Form & 53.20 & 42.67 & 10.53 \\
Usage & 15.79 & 8.77 & 7.02 \\
Meaning & 58.68 & 53.42 & 5.26 \\
Mean Score of Overall Aspects & 42.56 & 34.95 & 8.01 \\
\hline
\end{tabular}

Table 6 shows the comparison between the mean score of posttest between experimental class and control class in three aspects of vocabulary. From the tables above, it can be seen that the most influenced or improved aspect of vocabulary in experimental class and control class was form. However, the students in experimental class had more improved score (30.27) than the students in control class (8.03) on that aspect.

By taking three extracts from experimental class and three extracts of control class, the answers of the students in both classes will be described in the following details.

The first is the aspect of form. The difference score of the students in experimental class and control class in this aspect especially in pretest was 10.53 point. In this case, the students were asked to write the correct form of English words to complete the blank in the sentence. Below are the two extracts of the students in completing the sentence "The highest position in hotel is ...

Table 7: Student A1's answer in pretest and posttest of the form aspect

\begin{tabular}{|c|c|c|}
\hline $\begin{array}{c}\text { Correct } \\
\text { Answer }\end{array}$ & Pretest Answer & Posttest Answer \\
\hline $\begin{array}{l}\text { General } \\
\text { manager }\end{array}$ & Manager hotel and Suvevisor & General manager \\
\hline
\end{tabular}


Hardiyanti, Atmowardoyo, Salija : Playing Safmeds and ...

Table 8: Student B7's answer in pretest and posttest of the form aspect

\begin{tabular}{|c|c|c|}
\hline $\begin{array}{c}\text { Correct } \\
\text { Answer }\end{array}$ & Pretest Answer & Posttest Answer \\
\hline $\begin{array}{l}\text { General } \\
\text { manager }\end{array}$ & gues har & Jendral meqejer \\
\hline
\end{tabular}

From table 7 and table 8, it can be seen that at first the student E1 did not write the correct form of the definition of the terms given. Being confused to decide that, the student wrote both of them. However he failed. Fortunately, he was able to answer the question after the treatment. He wrote, "General manager" with the correct form. Meanwhile, student B1 also did not write the correct form. The student B1 also failed to decide the correct words. In this case she got zero point. After the treatment, student B7 was able to determine the concept of the words but she failed to write the correct form (table 4).

The second is usage. This time, the students should choose the appropriate words in order to complete the sentence. They should determine where and when they should put the words in a sentence. was better than the students in control class. In pretest and posttest, there were two correct answers of student A1 (from experimental class).

Table 9: Student A1's answer in pretest and posttest of the usage aspect.

\begin{tabular}{|c|c|}
\hline Pretest Answer & Posttest Answer \\
\hline bellboy & ACtivities \\
\hline mini bar & mini bor \\
\hline bellboy errand card & Bell boy \\
\hline bell boy captain & Bell boy confrol sheet \\
\hline bell boy control sheet & Bell boy cap tain \\
\hline activities & Bell boy errand card \\
\hline
\end{tabular}




\begin{tabular}{|c|c|}
\hline Pretest Answer & Posttest Answer \\
\hline bellhoy caption & bellboy coutrol sureet \\
\hline bellboy arraud card & berliboy capteain \\
\hline mini bar & mini bar \\
\hline activis & \\
\hline bellboy controu sneet & beliboy errand cart \\
\hline belliboy & activities \\
\hline
\end{tabular}

Data in table 9 and 10 shows the comparison between the answers of student A1 and student B7. Student B7 did not make any improvement before and after the treatment. This is because there were no correct answers that the student had in both pretest and posttest, especially in terms of aspect vocabulary usage.

The third is meaning. In this aspect, the mean score of the students in experimental class was also higher than the mean score of the students in control class. Then, the ability of determining the right concept refers to the word of the students in experimental class was better than the ability of determining the right concept refers to the word of the students in control class. Below are the example of answers of three questions by Student A1 and B7.

Table 11: Student A1's answer in pretest and posttest of the meaning aspect.

\begin{tabular}{|l|c|c|c|c|}
\hline \multirow{2}{*}{ Details } & \multicolumn{2}{|c|}{ Pretest } & \multicolumn{2}{c|}{ Posttest } \\
\cline { 2 - 5 } & $\begin{array}{c}\text { The True } \\
\text { Answer }\end{array}$ & $\begin{array}{c}\text { The Chosen } \\
\text { Answer } \\
\text { Answer } \\
\text { Chosen } \\
\text { Answer }\end{array}$ \\
\hline $\begin{array}{l}\text { Wheeled small vehicle to } \\
\text { transport luggage is called } \\
\ldots\end{array}$ & $\begin{array}{c}\text { Luggage } \\
\text { Cart }\end{array}$ & $\begin{array}{l}\text { Luggage Cart } \\
\text { Ansue }\end{array}$ & $\begin{array}{c}\text { Luggage } \\
\text { Cart }\end{array}$ & $\begin{array}{c}\text { Luggage } \\
\text { Cart }\end{array}$ \\
\hline $\begin{array}{l}\text { Someone who is responsible } \\
\text { of keeping the hotel linens is } \\
\text { a ... }\end{array}$ & Linen Maid & Linen Rack & $\begin{array}{c}\text { Linen } \\
\text { Maid }\end{array}$ & $\begin{array}{c}\text { Linen } \\
\text { Storage }\end{array}$ \\
\hline $\begin{array}{l}\text { "The Air Conditioner's } \\
\text { temperature is too low. Can } \\
\text { you give me that... I'm }\end{array}$ & Blanket & Pillow case & Blanket & Pillow case \\
\hline
\end{tabular}




\begin{tabular}{|l|c|c|c|c|}
\hline \multirow{2}{*}{ Details } & \multicolumn{2}{|c|}{ Pretest } & \multicolumn{2}{c|}{ Posttest } \\
\cline { 2 - 5 } & $\begin{array}{c}\text { The True } \\
\text { Answer }\end{array}$ & $\begin{array}{c}\text { The Chosen } \\
\text { Answer }\end{array}$ & $\begin{array}{c}\text { The True } \\
\text { Answer }\end{array}$ & $\begin{array}{c}\text { The } \\
\text { Chosen } \\
\text { Answer }\end{array}$ \\
\hline cold. & & & & \\
\hline
\end{tabular}

Table 8: Student B7's answer in pretest and posttest of the meaning aspect.

\begin{tabular}{|c|c|c|c|c|}
\hline \multirow[b]{2}{*}{ Details } & \multicolumn{2}{|c|}{ Pretest } & \multicolumn{2}{|c|}{ Posttest } \\
\hline & $\begin{array}{l}\text { The True } \\
\text { Answer }\end{array}$ & $\begin{array}{c}\text { The } \\
\text { Chosen } \\
\text { Answer }\end{array}$ & $\begin{array}{l}\text { The True } \\
\text { Answer }\end{array}$ & $\begin{array}{c}\text { The Chosen } \\
\text { Answer }\end{array}$ \\
\hline $\begin{array}{l}\text { Wheeled small } \\
\text { vehicle to transport } \\
\text { luggage is called. . }\end{array}$ & Luggage Cart & $\begin{array}{l}\text { Luggage } \\
\text { supplies }\end{array}$ & Luggage Cart & Luggage Cart \\
\hline $\begin{array}{l}\text { Someone who is } \\
\text { responsible } \\
\text { keeping the hotel } \\
\text { linens is a ... }\end{array}$ & Linen Maid & Linen rack & Linen Maid & Linen Store \\
\hline $\begin{array}{l}\text { "The Air } \\
\text { Conditioner's } \\
\text { temperature is too } \\
\text { low. Can you give } \\
\text { me that... . I'm } \\
\text { cold. }\end{array}$ & Blanket & $\begin{array}{l}\text { Head } \\
\text { Pillow }\end{array}$ & Blanket & Pillow case \\
\hline
\end{tabular}

The mean score of overall analytical statistical aspects in the posttest generally show possitivedifference on the three aspects of vocabulary. However, the most influenced or improved aspect of vocabulary in experimental class and control class was form. In this case, students in experimental class got higher score as well. This finding supported Milton's assumption (2009) that stated:

"Most able learners most recognize words by seeing them rather than listening them".

From Milton's statement, the researcher assumed that the student in experimental class got higher performance in the aspects of form because they had already been exposed to play SAFMEDS cards. It is very beneficial for the students because they not only can listen to the words because they have to pronounce them but they also can try their sight to recognize more words. In addition, based on Dale's Cone of Experience (1969), SAFMEDS can help students to get the very bottom of cone in 
Dale's theory. Students can have direct purposeful experience as they had already used their sight to read the clues in the front side of cards, and then their oral sense to say the answers in the back side of the cards, as well as use their hands to move on the every card in particular period.

\section{CONCLUSION}

There are two main research questions that had been tried to explore. From the data analysis it was found that the mean score of the students who were treated by using SAFMEDS in their vocabulary learning and the mean score of the students who were treated by using wordlist in their vocabulary learning were significantly different. Secondly, the researcher found that the aspect of vocabulary which was dominantly affected by the use of SAFMEDS cards is the aspect of vocabulary in term of form.

\section{REFERENCES}

Astika, I. G. (2016). Vocabulary Learning Strategies of Secondary School Students, $1(1), 1-18$.

Beverly, M., Hughes, J. C., \& Hastings, R. P. (2016).Using SAFMEDS to assist Language Learners to Acquire Second-Language Vocabulary. https://doi.org/10.1080/15021149.2016.1247577

Coxhead, A., Parkinson, J., \&Tu'amoheloa, F. (2017).Using Talanoa to develop bilingual word lists of technical vocabulary in the trades. https://doi.org/10.1080/13670050.2017.1374329

Dale, E. (1969).Audiovisual Methods in Teaching.Holt, Rinehart \& Winston, New York.New York: Dryden Press. Available online uploaded by Heidi Milia Anderson, Ph.D., Assistant Dean for Education Innovation, University of Kentucky.

Graf, S. \& J. Auman. (2005). SAFMEDS: A Tool to Build Fluency. Zero Brothers Software, Graf Implements, Version 1.0.

Kubina Jr., R. M., • Yurich, K. K. L., Durica, K. C., \& Healy, N. M. (2015).Developing Behavioral Fluency with Movement Cycles Using SAFMEDS. https://doi.org/10.1007/s10864-015-9232-1

Laufer, B. (1998). The Development of Passive and Active Vocabulary in a Second Language: Same Or Different?

Mehring, J. G. (2005). Developing Vocabulary in Second Language Acquisition: From Theories to the Classroom.

Meindl, J. N., Ivy, J. W., Milller, N., Williamson, R. L., \&Neef, N. A. (2013). An Examination of Stimulus Control in Fluency-Based Strategies: SAFMEDS and Generalization. https://doi.org/10.1007/s10864-013-9172-6 
138

ELT Worldwide Vol. 5 No. 2 (2018)

Hardiyanti, Atmowardoyo, Salija : Playing Safmeds and ....

Milton, J. (2009). Measuring Second Language Vocabulary Acquisition. Bristol: Short Run Predalss, Ltd.

Pekka, T. (2013). Why is Vocabulary Acquisition So Important in Second and Foreign Language? [WordDive Team]. Retrieved June 15, 2017, from http://www.worddive.com/blog/words-will-get-you-far-why-is-vocabularyacquisition-so-important-in-second-and-foreign-language/

Quigley, S. P. (2014). An Evaluation of Various SAFMEDS Procedures. 